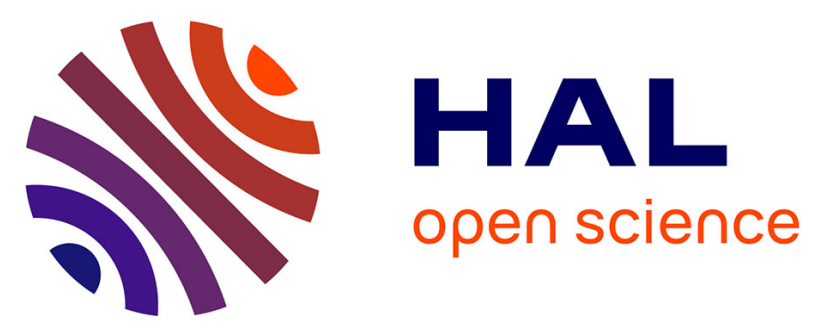

\title{
Hemp harvest time impacts on the dynamics of microbial colonization and hemp stems degradation during dew retting
}

Laurent Bleuze, Brigitte Chabbert, Gwenaëlle Lashermes, Sylvie Recous

\section{To cite this version:}

Laurent Bleuze, Brigitte Chabbert, Gwenaëlle Lashermes, Sylvie Recous. Hemp harvest time impacts on the dynamics of microbial colonization and hemp stems degradation during dew retting. Industrial Crops and Products, 2020, 145, pp.1-12. 10.1016/j.indcrop.2020.112122 . hal-02507232

\section{HAL Id: hal-02507232 \\ https://hal.science/hal-02507232}

Submitted on 26 May 2020

HAL is a multi-disciplinary open access archive for the deposit and dissemination of scientific research documents, whether they are published or not. The documents may come from teaching and research institutions in France or abroad, or from public or private research centers.
L'archive ouverte pluridisciplinaire HAL, est destinée au dépôt et à la diffusion de documents scientifiques de niveau recherche, publiés ou non, émanant des établissements d'enseignement et de recherche français ou étrangers, des laboratoires publics ou privés.

\section{(ㅇ)(1) $\$$}

Distributed under a Creative Commons Attribution - NonCommercial - NoDerivatives 44.0 
Post-print version (25/01/2020) of the paper published in Industrial Crops and Products, volume 145, March 2020, 112122

https://www.sciencedirect.com/science/article/abs/pii/S0926669020300388

https://doi.org/10.1016/j.indcrop.2020.112122

\title{
Hemp harvest time impacts on the dynamics of microbial colonization and hemp stems degradation during dew retting
}

\author{
Laurent Bleuze, Brigitte Chabbert, Gwenaëlle Lashermes, Sylvie Recous* \\ Université de Reims Champagne Ardenne, INRAE, FARE Laboratory, 51100 Reims, France
}

Received 8 August 2019, Received in revised form 7 Jan 2020, Accepted 10 January 2020, Available online 23 January 2020

*Corresponding author: Sylvie Recous, sylvie.recous@inrae.fr, INRAE, UMR FARE, 2 esplanade Roland Garros, 51100

Reims, France

\begin{abstract}
Dew retting, a selective microbial degradation of industrial hemp (Cannabis sativa L.) stems occurring after harvest under local climatic conditions, is an important field process for plant fibre uses. We investigated how the crop harvest time, which depends on the hemp valorization strategy envisaged by the farmer, affected the initial stem quality and the subsequent microbial degradation dynamics of retting. We used simulated rains and dews to carry out retting under laboratory conditions for 42 days at $15^{\circ} \mathrm{C}$ with hemp stems harvested at different times (flowering and seed maturity stage). The microbial colonization and changes in the bast tissue architecture were tracked from day 0 to day 42 using colorimetry, surface infrared spectroscopy, chemical analysis, and scanning electron microscopy. The early changes in the microbial colonization and color of the stem surface and the degradation of the bast tissue parenchyma followed the same pattern during retting for the two stem qualities. However, the kinetic of these processes was 7 to 14 days faster for the flowering stems, which had higher initial soluble and lower lignin contents than the mature stems. The results suggest a promising potential use of colorimetry and surface infrared spectroscopy data as candidate indicators for the dew retting progress in the field. Besides the results of this study indicate that differences in hemp stem chemical composition due to different crop harvest time significantly impacted microbial colonization, biofilm formation and eventually dew retting duration.
\end{abstract}

\section{Highlights}

- Hemp harvest time impacts on the dynamics of stems dew retting

- Hemp stems harvested at hemp flowering and maturity differ in chemical composition

- Colorimetry and ATR-FTIR analyses show dynamic of biofilm formation on hemp stem surface

- Fiber bundles decohesion is faster for the floweringharvested stems

\section{Keywords}

Biodegradation; Cannabis sativa L.; Dew retting; Hemp; Litter layer; Microbial colonization;

\begin{abstract}
Abbreviations
ANOVA, one-way analysis of variance; ATR, attenuated total reflectance; C, carbon; CEL, cellulose; DNS 3,5-dinitrosalicylic acid; CWR, cell wall residue; DM, dry matter; FLO, flowering stage; FTIR, Fourier transform infrared; HEM, hemicellulose; HPAEC-PAD, high-performance anion exchange chromatography with pulsed amperometric detection; LIG, lignin; MAT, seed maturity stage; N, nitrogen; PCA, principal component analysis; PGase, polygalacturonase; SEM, scanning electron microscopy; SOL, soluble;
\end{abstract}


Post-print version (25/01/2020) of the paper published in Industrial Crops and Products, volume 145, March 2020, 112122 https://www.sciencedirect.com/science/article/abs/pii/S0926669020300388 https://doi.org/10.1016/j.indcrop.2020.112122

\section{Introduction}

Hemp (Cannabis sativa L. vulgaris) is a multi-use crop with different valorizations for all the plant parts (seeds, stem). The most widespread industrial applications concern the bast fibres located in the outer region of the stem (Bouloc, 2006; Amaducci and Gusovius, 2010). After harvest, the first step in the processing chain is retting, a natural selective and partial biodegradation of the bast tissues of the stems left on the soil surface that is achieved by microorganisms. Retting facilitates the hemp stem defibration, preserving fibre quality during mechanical decortication (Tahir et al., 2011; Requilé et al., 2018; Sisti et al., 2018). However, the relationship between harvest time and microbial colonization and ultimately retting duration is poorly known. Harvest date is a key component of hemp management, and its choice depends on the farmer's strategy of crop use. In France, hemp harvest at the full-flowering stage uses only the bast fibres and hurds (xylem) while hemp harvest at seed maturity uses the bast fibres, hurds, and seeds (Bouloc, 2006; Amaducci et al., 2015). The choice of harvest time is leading to different chemical and tissue architectural features of harvested hemp stems, which have different maturity states (Keller et al., 2001; Crônier et al., 2005), and in different climatic conditions occurring during the dew retting process (Mediavilla et al., 2001; Bennett et al., 2006; Liu et al., 2015).

The changes in the stem quality characteristics (chemical composition and tissue architecture) and in the environmental conditions with respect to harvest time influence the microbial retting process, as observed during the decomposition of other crop residues (Coppens et al., 2006; Machinet et al., 2011). To date, little work has been done to study the effect of morphological and chemical quality of hemp stems on microbial colonization dynamics during dew retting (Bennett et al., 2006; Liu et al., 2015; Mazian et al., 2018; Müssig and Martens, 2003). In addition, the studies performed in the field suffered from confounding effects between the initial stem quality and climatic conditions during retting, two factors that vary with the harvest date. Therefore, an objective evaluation of the impact of hemp quality on dew retting dynamics has not yet been conducted.

The aim of this work was to study the effect of the initial quality of hemp stem (resulting from stems collected at either the flowering or maturity stage) on the dynamics of dew retting and the short-term consequences on the evolution of the substrate. A controlled experimental approach inspired by the decomposition studies of mulches, which mimics, controls and reproduces the environmental conditions of rain, air temperature, humidity and lighting, was used. The hypothesis was that hemp stems collected at the flowering stage will induce an earlier microbial colonization, a faster degradation and reduce retting duration compare to mature stems and that the difference in kinetics will be accurately observable and therefore quantifiable by the stem colonization, colour and tissue architecture changes.

\section{Materials and Methods}

\subsection{Plant material and soil sampling}

Hemp (Cannabis sativa L., variety Fedora 17) was cultivated at Colombey-les-Deux-Eglises, France $\left(48^{\circ} 22^{\prime} \mathrm{N}\right.$, $\left.4^{\circ} 89^{\prime} \mathrm{E}\right)$. The stems were sampled at two growing stages in 2015, at the end of July and in early September, corresponding to the flowering (FLO stems) and seed maturity (MAT stems) stages, respectively, which correspond to Mediavilla growth stage codes 2302 and 2306 (Mediavilla et al., 1998). The stems were cut, dried at $40{ }^{\circ} \mathrm{C}$ in a forced-air oven for one week and then stored at room temperature. The median parts of the stems were cut into $10 \mathrm{~cm}$ portions as previously described (Bleuze et al., 2018). In this way, we minimized the heterogeneity of the initial chemical composition, which depends upon the position within the stem, as highlighted in earlier works (Crônier et al., 2005). Subsamples of FLO and MAT stem portions were cut into small pieces $(4-5 \mathrm{~mm})$, and the chemical composition was determined by the proximate analysis (soluble SOL, hemicellulose HEM, cellulose CEL and lignin-like LIG contents), a previously described method (Van Soest, 1963). Soluble compounds extracted by Van Soest neutral detergent solution contain mainly the cytosoluble component (proteins, sugar) and some cell wall pectins (Van Soest et al., 1991). The water-soluble C content was measured in 3 replicates according to a previous study (Nicolardot et al., 2007), and the $\mathrm{N}$ content was measured using an elemental analyser (Euro EA, EUROVECTOR, Italy). Chemical characteristics of the FLO and MAT whole stems are reported in Table 1.

Table 1 Chemical characteristics of the two hemp stem qualities sampled at flowering stage (FLO stems) and maturity stage (MAT stems)

\begin{tabular}{|c|c|c|c|c|c|c|}
\hline & Var & oest frac & ns (g/kg & & \multicolumn{2}{|c|}{$\begin{array}{c}\text { Water } \\
\text { soluble C } \\
\text { g/kg DM } \\
\end{array}$} \\
\hline & SOL & HEM & CEL & LIG & & \\
\hline FLO & $220 \pm 10$ & $223 \pm 12$ & $454 \pm 10$ & $102 \pm 3$ & $42 \pm 3$ & $6 \pm 0$ \\
\hline MAT & $162 \pm 7$ & $170 \pm 7$ & $549 \pm 11$ & $119 \pm 8$ & $25 \pm 2$ & $7 \pm 0$ \\
\hline
\end{tabular}

Soil was collected from the top $10-\mathrm{cm}$ layer from the same plot cropped with the MAT stems (early September 2015) and was stored at $4{ }^{\circ} \mathrm{C}$. Only one soil was used with both qualities of stems, to avoid kinetic differences that would not be strictly related to the initial quality of the stems. The soil texture is silty clay loam (FAO) with $38.8 \%$ clay, $59.2 \%$ silt and $2 \%$ sand. The initial total carbon $(\mathrm{C})$ and nitrogen $(\mathrm{N})$ contents were 15.8 and $1.8 \mathrm{~g} \mathrm{~kg}^{-1}$ soil, respectively. The measured $\mathrm{pH}_{\mathrm{H} 2 \mathrm{O}}$ was 6.97 . Prior to incubation, the moist soil sample was sieved $(<4 \mathrm{~mm})$, and the stones and plant residues were removed. The sample was kept at $4{ }^{\circ} \mathrm{C}$ to prevent microbial activities until the start of the experiment. 
Post-print version (25/01/2020) of the paper published in Industrial Crops and Products, volume 145, March 2020, 112122 https://www.sciencedirect.com/science/article/abs/pii/S0926669020300388 https://doi.org/10.1016/j.indcrop.2020.112122

\subsection{Experimental setup and retting protocol}

The experimental setup consisted of twenty PVC columns ( 5 destructive sampling dates x 2 hemp qualities x 2 replicates per date) containing a $10-\mathrm{cm}$ layer of soil onto which hemp stems were displayed and lined up to form a litter layer (Fig. 1ab). This setup was derived from that of Bleuze et al. (2018). The PVC columns were incubated in a climatic chamber in which the environmental parameters (air temperature, relative humidity, lighting, rainfall and dew levels) and both the litter layer and soil characteristics (quality, quantity, and density) were controlled to process hemp dew retting at the laboratory scale (Fig. 1c).

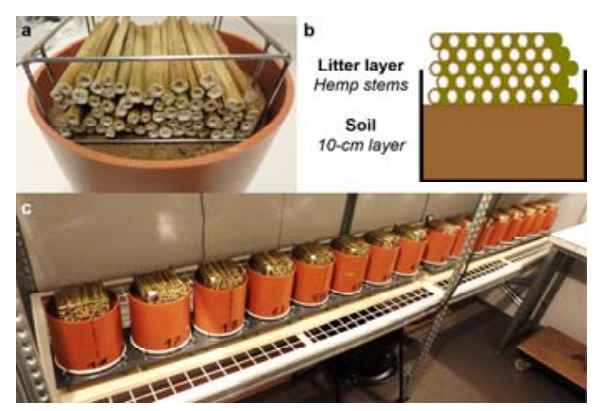

Fig. 1 Experimental setup. Hemp litter layer (a), a scheme of an experimental column (b) and experimental columns in the climatic chamber (c)

The soil water content was adjusted to $20 \mathrm{~g} \mathrm{H}_{2} \mathrm{O} 100 \mathrm{~g}^{-1}$ dry soil with deionized water, and the soil bulk density was set at $1.3 \mathrm{~g} \mathrm{~cm}^{-3}$. The soil was placed in the columns to form a $10 \mathrm{~cm}$-high soil layer by adding the corresponding mass ( $2426 \mathrm{~g}$ of moist soil). Before the start of the incubation, the soil-filled columns were preincubated for $24 \mathrm{~h}$ in the climatic chamber at $15{ }^{\circ} \mathrm{C}$ with a relative humidity of $70 \%$. The experimental strategy was to focus on the number of stems per unit area in relation to the seeding rate, which remains the same at the two hemp harvest stages. The hemp litter layers consisted of 120 stems $10 \mathrm{~cm}$ in length (average crop density of 265 stems per $\mathrm{m}^{2}$ ), which has necessarily led to differences in the other characteristics of the litter layers due to variations in the physical properties of the FLO and MAT stems. This high plant density was chosen according to the agronomy of industrial hemp for fiber purpose in eastern France (Terres Inovia, 2017; Struik et al., 2000). Thus, the FLO stems were on average heavier and less dense than the MAT stems, which gave rise to a thicker and less dense litter layer (Table 2). The average dry mass of the hemp litter layers was $71.4 \pm 6.3 \mathrm{~g}$ and $56.0 \pm 3.6 \mathrm{~g}$ for the FLO and MAT litter layers, respectively. The dried hemp stems were remoistened with deionized water at $4{ }^{\circ} \mathrm{C}$ for $24 \mathrm{~h}$ (Bleuze et al., 2018). Deionized water was used to adjust the soil water content and moisten the stems to standardize the applied water composition. The excess water (the free water contained in the pith hole) was drained prior to incubation. The average initial moisture content of the hemp stems was different for the two qualities and reached 0.69 and $0.80 \mathrm{~g} \mathrm{H}_{2} \mathrm{O} \mathrm{g}^{-1} \mathrm{DM}$ for the FLO and MAT stems, respectively.

Table 2 Hemp litter layer characteristics of the two hemp qualities (FLO stems and MAT stems)

\begin{tabular}{lll}
\hline & FLO stems & MAT stems \\
\hline Stem diameter $(\mathrm{cm})$ & $0.4-1$ & $0.4-1$ \\
Litter layer thickness $(\mathrm{cm})$ & 5 & 3 \\
$\begin{array}{l}\text { Litter layer density }\left(\mathrm{kg} \mathrm{m}^{-3}\right) \\
\begin{array}{l}\text { Initial litter layer dry matter } \\
(\mathrm{g} \mathrm{layer})\end{array}\end{array}$ & 142 & 167 \\
$\begin{array}{l}\text { Initial stem moisture }\left(\mathrm{g} \mathrm{H}_{2} \mathrm{O} \mathrm{g}^{-1}\right. \\
\mathrm{DM})\end{array}$ & $0.69 \pm 0.08$ & $0.80 \pm 0.06$ \\
$\begin{array}{l}\text { Initial stem saturation moisture } \\
\left(\mathrm{g} \mathrm{H} \mathrm{O} \mathrm{g}^{-1} \mathrm{DM}\right)\end{array}$ & $1.99 \pm 0.25$ & $2.47 \pm 0.21$ \\
$\begin{array}{l}\mathrm{Initial} \mathrm{stem} \mathrm{residual} \mathrm{moisture} \\
\left(\mathrm{g} \mathrm{H} \mathrm{O} \mathrm{g} \mathrm{g}^{-1} \mathrm{DM}\right)\end{array}$ & $0.03 \pm 0.0$ & $0.04 \pm 0.00$ \\
\hline
\end{tabular}

The air temperature and relative humidity were set and regulated at $15{ }^{\circ} \mathrm{C}$ and $70 \%$ moisture content, respectively. A monitoring system recorded both values every 15 min using sensors (174 H, TESTO, Germany), and the data were analysed with dedicated software (Comfort Basic 5.0, TESTO, Germany). A 12-hour daily lighting cycle was imposed using an LED lighting system (Rail 36 watts, Gemma LED, Sweden) that mimicked natural lighting. An equivalent rainfall of $10 \mathrm{~mm}$ was produced once per week with a rain regime of $6 \mathrm{~mm} \mathrm{~h}^{-1}$ using rain simulators and deionized water. An equivalent of $0.2-\mathrm{mm}$ dew was applied three times a week by spraying with deionized water. These climatic characteristics were chosen to be in a realistic range on the basis of the mean climatic conditions over the past five years in hemp growing areas during retting time in early September.

\subsection{Hemp litter layer and top soil layer sampling}

Two randomly selected columns per hemp quality were destructively sampled at the beginning of the incubation (initial state) and after 7, 14, 28 and 42 days (Fig. 2). Each litter layer was divided into two samples by separating the stems from the left side from those on the right side, resulting in four replicates for each hemp quality and sampling date. Three stems of each sample were air-dried at $40{ }^{\circ} \mathrm{C}$ for $72 \mathrm{~h}$ to determine the DM loss and moisture content and perform the surface analysis. The rest of the stems were immersed for $5 \mathrm{~min}$ in liquid nitrogen and then stored at $-20{ }^{\circ} \mathrm{C}$ until analysis. The bast tissues were then peeled from the frozen stem samples prior to the chemical composition analysis and enzymatic activity assays. The 2 -cm topsoil layers of the soil were sampled and stored at $-20{ }^{\circ} \mathrm{C}$ until analysis. 


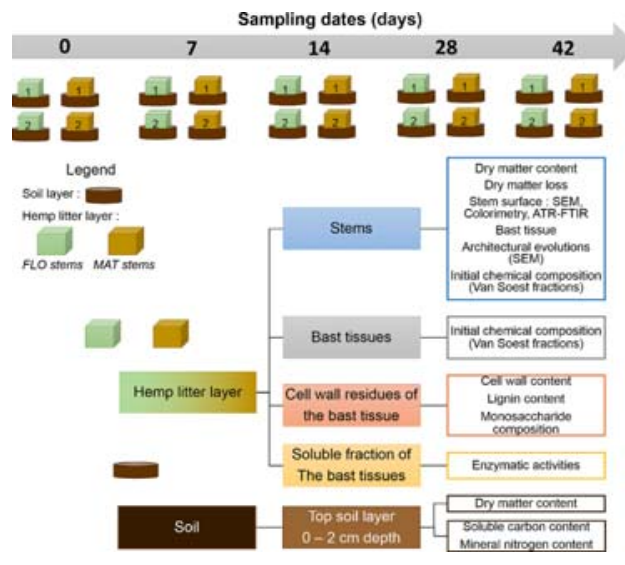

Fig. 2. Sampling of hemp and soil and analysis diagram

\subsection{Stem surface colour measurement}

The stem surface colour was measured for a set of 3 stems per sample with a colorimeter (CR-400, Konica Minolta, Japan) using the CIELab colour space system as previously described in Bleuze et al. (2018). The CIELAB colour space is a three-dimensional colour space $\left(\mathrm{L}^{*}, \mathrm{a}^{*}\right.$, and $\mathrm{b}^{*}$ ) where the $\mathrm{L}^{*}$ value corresponds to lightness (black $=0$ to white $=100)$, the $\mathrm{a}^{*}$ value indicates the redness/greenness component and the $b^{*}$ value describes the yellowness/blueness component (McGuire, 1992).

\subsection{Chemical composition analysis of the outermost stem layer}

The chemical changes of the outermost layer of the stem were characterized by surface infrared spectroscopy. The spectra were acquired by attenuated total reflectance (ATR) using a Fourier transform infrared (FTIR) spectrometer (CARY 630, Agilent, USA). The measurements were performed in six replicates on 3 stem sections per sample. The spectra were obtained and corrected as previously described (Bleuze et al., 2018).

\subsection{Microscopy imaging of hemp stem surface and bast tissue architecture}

Thick cross-sections $(5 \mathrm{~mm})$ and longitudinal sections $(10 \mathrm{~mm})$ were hand-cut from 3 frozen stems per sample using a razor blade. The sections were sampled from the median part of a $10-\mathrm{cm}$ long stem to minimize the edge effects. The sections were dried in a forced-air oven at $40^{\circ} \mathrm{C}$ for $2 \mathrm{~h}$ prior to being observed with a table-top scanning electron microscope (SEM) (TM-1000, Hitachi, Japan) at an accelerating voltage of $15 \mathrm{kV}$.

\subsection{Chemical analysis}

Subsamples of the initial FLO and MAT bast tissues were isolated by manual peeling, cut by hand into small pieces (4-5 $\mathrm{mm}$ ) and analysed to determine the initial chemical composition by proximate analysis to determine the SOL, HEM, CEL, LIG contents (Van Soest, 1963). The bast tissues of 8 stems per sample were freeze-dried, hand-cut and then ground with a ball crusher (MM 2000, Retsch, Germany) for three min. The cell wall residues (CWR) were obtained from the ground bast tissues, which were successively washed with deionized water and ethanol and then dried in a forced-air oven at $50{ }^{\circ} \mathrm{C}$ for $72 \mathrm{~h}$. The bast tissue cell wall contents were determined by weighing the CWR sample. The LIG content of the CWR was measured using a spectrophotometry protocol previously described (Johnson et al., 1961) involving acetyl bromide and $10 \mathrm{mg}$ of the CWR sample. This method was used to obtain a more precise quantification of the LIG content than the quantification based on the Van Soest determination. The CWR polysaccharides were hydrolysed into sugar monomers using two-step sulfuric acid hydrolysis (Belmokhtar et al., 2013). The sugar monomers were separated by high-performance anion exchange chromatography with pulsed amperometric detection (HPAEC-PAD) on a DIONEX CarboPacTM PA-1 analytical column (4 x $250 \mathrm{~mm}$, Thermo Fisher Scientific, USA). The monosaccharide contents were quantified in triplicate using 2deoxy-D-ribose as the internal standard and standard solutions of the neutral sugars and galacturonic acid monomers (Lashermes et al., 2016).

\subsection{Enzymatic activities}

Polygalacturonase (PGase) activity was determined on the fraction extracted from the bast tissues (Fig. 2). The extract was obtained from $400 \mathrm{mg}$ equivalent dry mass of bast tissues, which were blended in $100 \mathrm{~mL}$ of a $50 \mathrm{mM}$ phosphate buffer ( $\mathrm{pH} 7$ ) for $1 \mathrm{~min}$ prior to filtration through a GF/A filter. The PGase activity was measured in duplicate for each sample using the 3,5-dinitrosalicylic acid (DNS) reagent (Miller, 1959) and a galacturonic acid calibration curve as previously described (Bleuze et al., 2018). The PGase activity assay was performed for $1 \mathrm{~h}$ at $25^{\circ} \mathrm{C}$ at $\mathrm{pH} 7$, and the reaction was stopped by adding $500 \mu \mathrm{L}$ of DNS. The solutions were then boiled in water for $5 \mathrm{~min}$, and the absorbance was measured at $540 \mathrm{~nm}$ using a spectrophotometer (Helios Gamma, Thermo Fisher Scientific, USA). The PGase activity is expressed as nmol $\mathrm{g}^{-1}$ dry bast tissues $\mathrm{min}^{-1}$. 
Post-print version (25/01/2020) of the paper published in Industrial Crops and Products, volume 145, March 2020, 112122 https://www.sciencedirect.com/science/article/abs/pii/S0926669020300388 https://doi.org/10.1016/j.indcrop.2020.112122

\subsection{Soil analysis}

The soil mineral $\mathrm{N}$ content was determined for each column in the soil solution after $25 \mathrm{~g}$ soil (DM basis) were extracted with $100 \mathrm{~mL}$ of a $1 \mathrm{M} \mathrm{KCl}$ solution. The concentrations of $\mathrm{N}-\mathrm{NH}_{4}{ }^{+}$were assayed using salicylate and dichloroisocyanurate (Krom, 1980), and the concentrations of $\mathrm{N}-\mathrm{NO}_{3}{ }^{-}$were measured by hydrazine reduction using the flow colorimetry method (TRAACS 2000, Bran and Luebbe) (Kamphake et al., 1967). The mineral $\mathrm{N}$ content was calculated by summing the contents of $\mathrm{N}_{-} \mathrm{NO}_{3}{ }^{-}$and $\mathrm{N}-\mathrm{NH}_{4}{ }^{+}$. The soluble $\mathrm{C}$ content in the soil was determined in the same samples according to a previous method (Barcelona, 1984), which consisted of oxidation at $100{ }^{\circ} \mathrm{C}$ in persulfate medium and measuring the produced $\mathrm{CO}_{2}$ by infrared with an autoanalyser (1030, OI Analytical, College station, Texas, USA).

\subsection{Statistical analysis}

A one-way analysis of variance (ANOVA) was performed on the obtained values followed by Holm-Sidak method for pairwise comparison with a significance level of probability set at alpha $<0.05$ to assess the effect of the stem quality on the stem loss of dry matter (DM) and moisture content, chemical composition of the bast tissues (lignin and monosaccharides contents) and the enzyme activities. ANOVAs were performed using SigmaPlot ${ }^{\circledR}$ software (version 12.0, Systat Software, USA). The Holm-Sidak method was used to perform pairwise multiple comparison procedures. A statistical analysis of the ATR-FTIR spectra was performed with a principal component analysis (PCA) using Unscrambler® X software (CAMO, Germany).

\section{Results}

\subsection{Evolution of the stems and topsoil layer}

\subsubsection{Stem surface colonization}

The SEM surface observations of the stems before retting showed some trichomes and remnants of trichomes and a very limited presence of microorganisms (Fig. 3ab). On day 7 , microbial colonization was revealed with the presence of both bacteria and fungi on the FLO and MAT stems (Fig. $3 \mathrm{~cd}$ ) as reported previously (Fernando et al., 2019). However, whereas the microbial colonization was widespread on the surface of the FLO stems (Fig. 3c), that on the MAT stems remained mostly limited to the trichome spots (Fig. 3d). On day 28, microbial colonization on the FLO stems had spread, with mycelium covering the whole epidermis surface (Fig. 3e) and a biofilm appearing on day 42 (Fig. 3g). Colonization on the MAT stems was slower, and development on day 42 was equivalent to that on the FLO stems on day 28.
DAYS
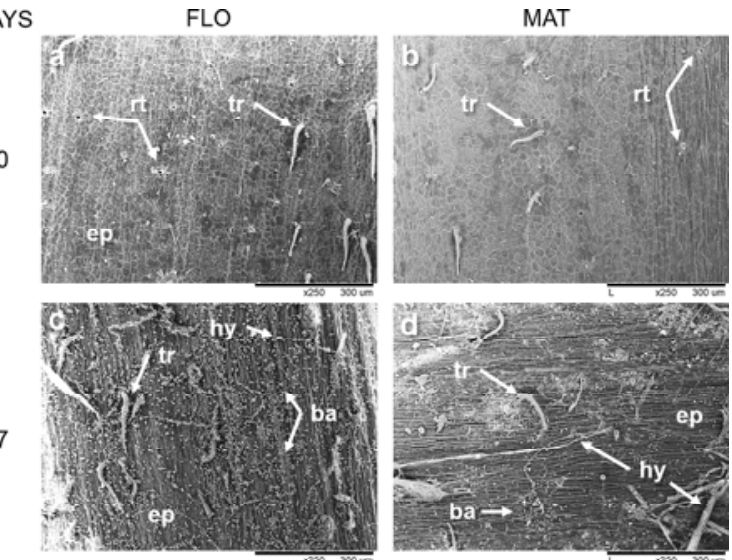

28
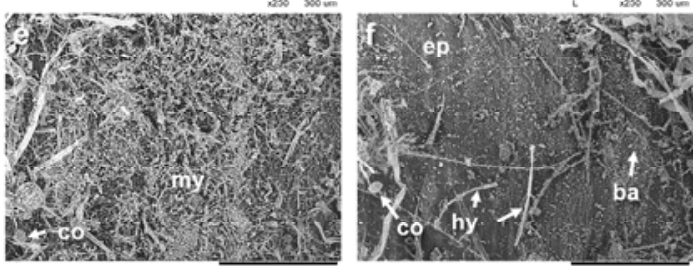

42
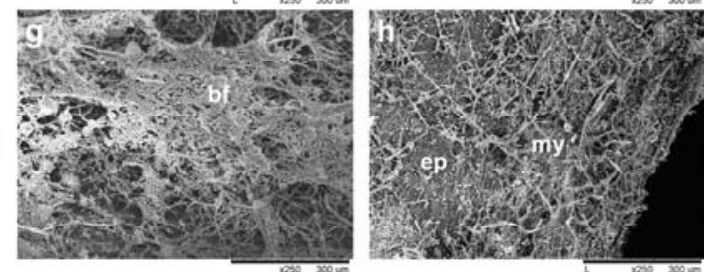

Fig. 3 SEM images of the stem surface portions of FLO (a, c, e, and g) and MAT stems (b, d, f, and h) during retting. Before retting (a,b), after 7 days (c,d), 28 days (e,f) and 42 days (g,h) of retting; (ba) bacteria, (bf) biofilm, (co) conidiophore, (ep) epidermis, (hy) hyphae, (my) mycelium, (rt) remnant of trichome, (tr) trichome and (xy) xylem. Scale bar $=300 \mu \mathrm{m}$.

\subsubsection{Stem surface infrared analysis}

The principal component analysis (PCA) results of the ATR-FTIR spectra for the FLO and MAT stems showed that the first two components explained approximately $90 \%$ of the variability in the spectra (Fig. 4). The score charts revealed a separation along the first principal component (PC-1) axis, responsible for $80 \%$ variability, between the samples from days 0 and 7 and the samples from day 14 to day 42 (Fig. 4ab), indicating changes in surface chemical properties over time during retting for both hemp qualities. However, regarding the MAT stems, few spectra from days 14 and 28 overlapped with the spectra from days 0 and 7 , revealing a higher heterogeneity in the retting progression for the MAT stems than for the FLO stems. The PC-1 loadings were strictly equivalent for both the FLO and MAT stem spectra and positively correlated with two bands at 2846 and $2914 \mathrm{~cm}^{-1}$ corresponding to the $\left(-\mathrm{CH}_{2}\right)$ stretching vibrations (Fig. $4 \mathrm{c}$ ), which are related to fatty compounds such as the cutin and waxes of the stem cuticle (Akin et al., 2004; Heredia-Guerrero et al., 2016). 
Post-print version (25/01/2020) of the paper published in Industrial Crops and Products, volume 145, March 2020, 112122 https://www.sciencedirect.com/science/article/abs/pii/S0926669020300388 https://doi.org/10.1016/j.indcrop.2020.112122

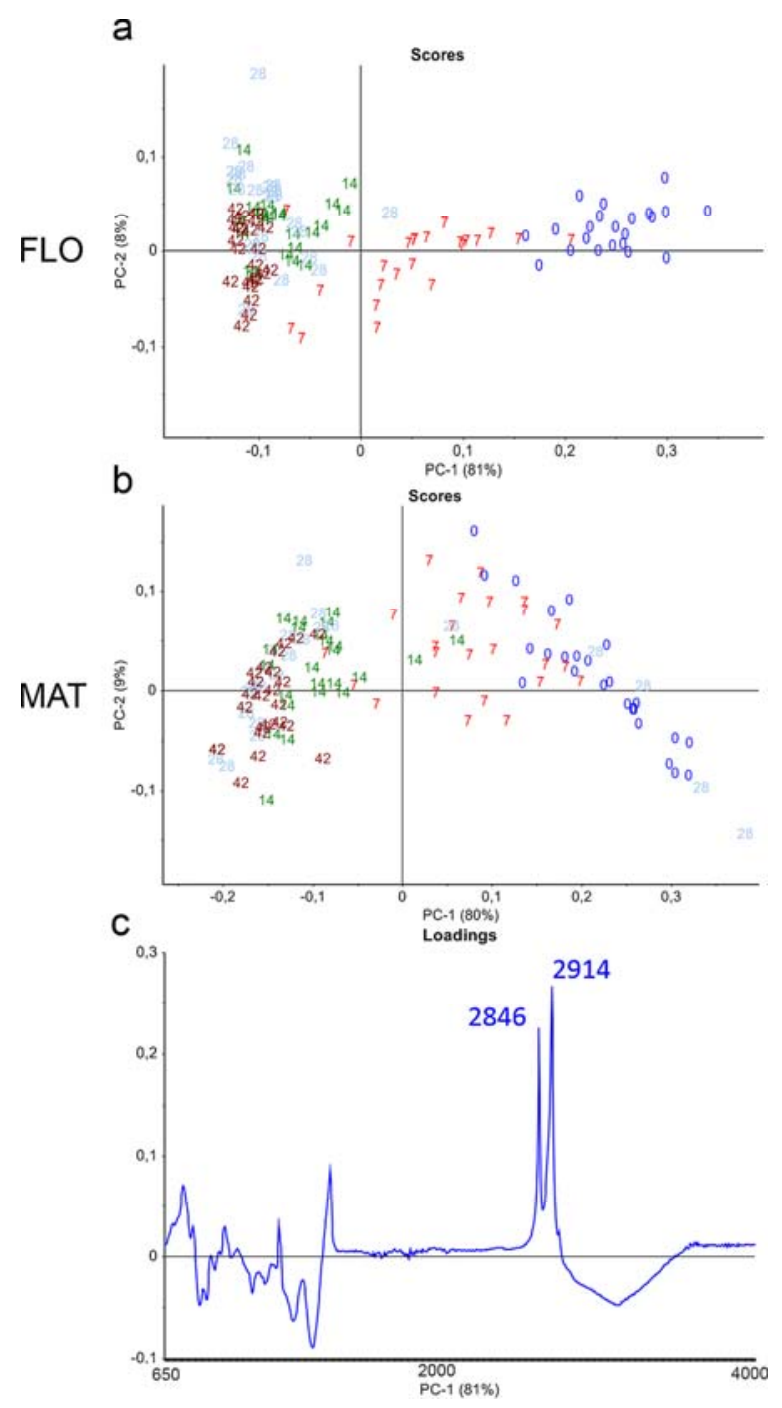

Fig. 4 PCA of the ATR-FTIR spectra of the FLO and MAT stem surfaces obtained during retting. Score loadings of FLO (a), MAT (b) and FLO \& MAT (c). The numbers correspond to the sampling date; the score loadings correspond to PC-1.

\subsubsection{Stem surface color}

The visual observation of the litter layers showed that there was a difference in the colour of the stems at the initial stage: the FLO stems were bright green, while the MAT stems were a bright camel-like colour (Fig. 5a,b). The stems became progressively pale yellow and then dark grey over time. However, this colour evolution was slower for the MAT stems (Fig. 5c-h). Moreover, we observed the progressive microbial colonization of the stem surfaces, visible by the presence of fungal hyphae and black spots; however, this colonization was delayed for the MAT stems (Fig. 5c-h), e.g., half of the FLO stems were colonized from day 7, while only a few MAT stems were colonized at this date (Fig. $5 \mathrm{c}, \mathrm{d})$. These changes in the stem surface colour, quantified by CIELab colorimetry, revealed a significant decrease in both $L^{*}$ (lightness) and $b^{*}$ (yellowness/blueness) values but a steady value for the $\mathrm{a}^{*}$ (redness/greenness) values (data not shown) of both hemp qualities (Fig. 6a). The colour changes occurred earlier for the FLO stems than for the MAT stems but followed the same pattern overall when expressed in relative change with respect to day 0 (Fig. 6 b). The color transition was already complete at day 28 for the FLO stems but was achieved only on day 42 for the MAT stems. As change in color can result from chemical modification of the stem surface, we study the possible correlation between the main factors shewing highest variation during retting as the whole process. The changes in colour ( $\mathrm{L}^{*}$ and particularly $\mathrm{b}^{*}$ values) were correlated with the changes in the absorbance of the infrared bands previously measured $\left(2914 \mathrm{~cm}^{-1}\right.$ absorbance $=0.0075 \mathrm{~b}^{*}-0.0621$, $\mathrm{R}^{2}=0.80 ; 2846 \mathrm{~cm}^{-1}$ absorbance $=0.0063 * \mathrm{~b}-0.0507$, $\left.\mathrm{R}^{2}=0.80\right)$.

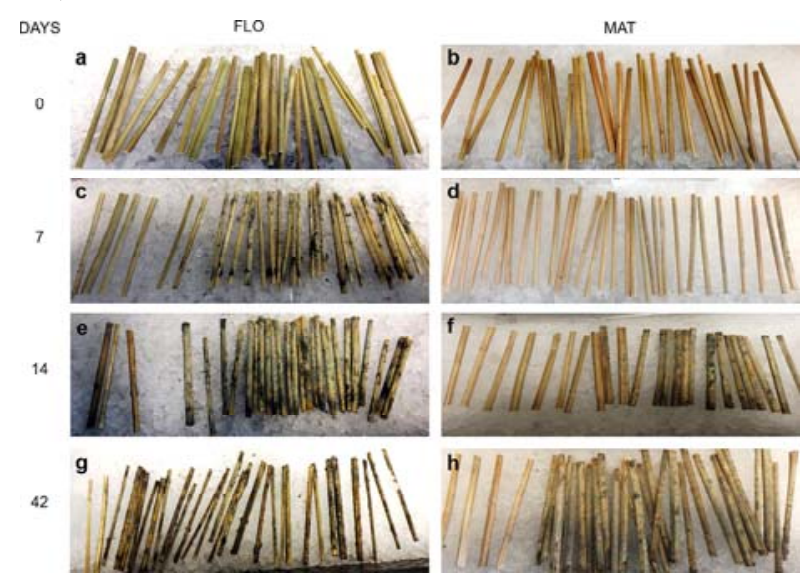

Fig. 5 Visual observations of the litter layer evolution before and during retting. FLO stems (a, c, e, and g) and MAT stems (b, d, f, and h); before retting $(\mathrm{a}, \mathrm{b})$ and after $7(\mathrm{c}, \mathrm{d}), 14(\mathrm{e}, \mathrm{f})$, and 42 days $(\mathrm{g}, \mathrm{h})$. Stem portion length $=10 \mathrm{~cm}$.
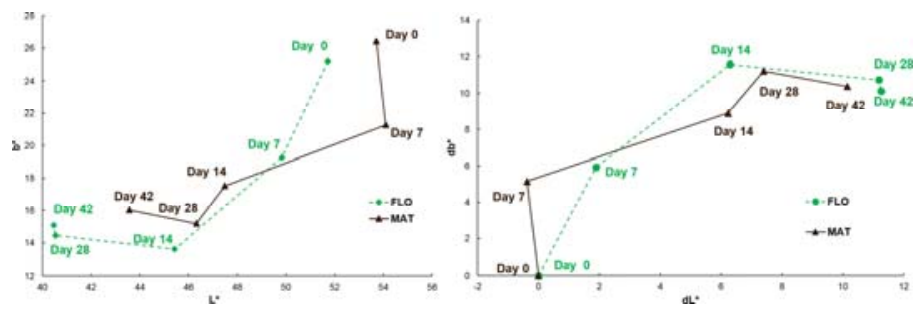

Fig. 6 Stem surface colour changes during retting measured by colorimetry (CIELab), considering the $\mathrm{L}^{*}$ (lightness) vs $\mathrm{b}^{*}$ (yellowness/blueness) components of colour (a) and relative change compared to day 0 (b).

\subsubsection{Stem DM and topsoil soluble C}

The loss of stem DM was about $10 \%$ for both the FLO and MAT stems after one week of incubation (Fig. 7a). However, from day 14, a significantly higher DM loss was 
observed for the FLO stems than for the MAT stems. The moisture content of the stems decreased sharply during the first week for both the FLO and MAT stems (Fig. 7b) and then remained stable at approximately $0.25 \mathrm{~g} \mathrm{H}_{2} \mathrm{O} \mathrm{g}^{-1} \mathrm{DM}$ until day 42 , with no significant differences between the two qualities.

A transient increase in the soluble $\mathrm{C}$ content of the topsoil layer was observed for the FLO stems at day 7, followed by a decrease, which was observed until day 42 (Fig. $7 \mathrm{c})$. For the MAT stems, the soluble $\mathrm{C}$ content in the soil was constant until day 7 and then slightly decreased until day 42 . In the same layer, the dynamics of the mineral $\mathrm{N}$ content were similar for both stems, with a large increase during the first 7 days, followed by a sharp decrease until day 42; there was no significant difference between the two qualities with respect to time (Fig. 7d).

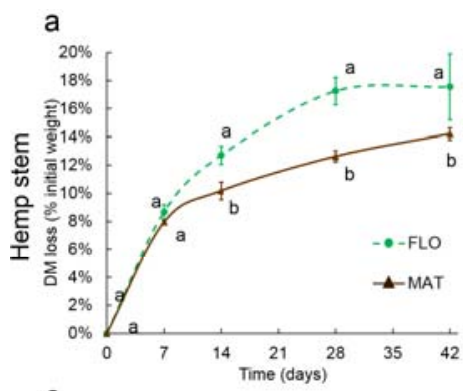

b
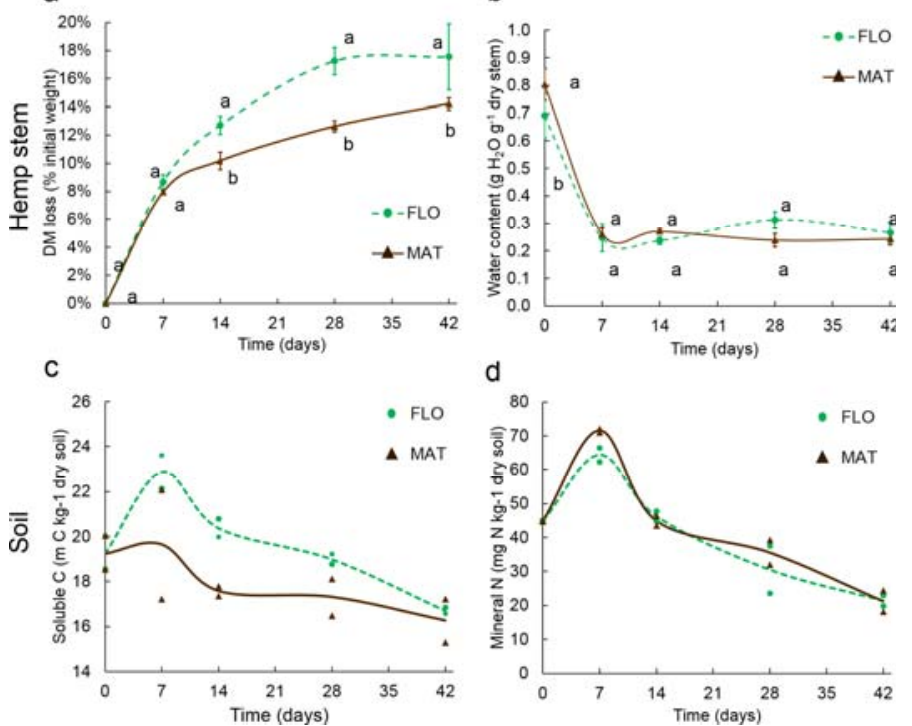

d

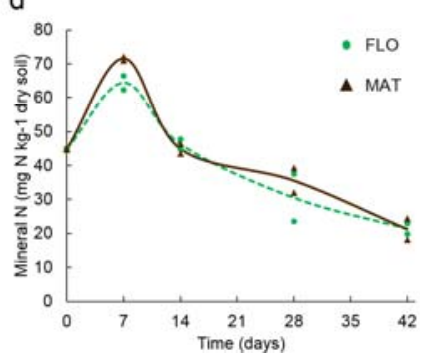

Fig. 7 Evolution of the DM loss (a) and moisture content (b) of hemp stems and of the soluble $\mathrm{C}$ (c) and mineral N (d) contents in the topsoil layer $(0-2 \mathrm{~cm})$ during retting $\left(42\right.$ days at $15{ }^{\circ} \mathrm{C}$ and $70 \%$ air relative moisture). Values with different letters are significantly different at a level of $5 \%$ for DM loss and moisture content. Values represent the mean of 6 replicates of stems ( \pm standard error), and the curve corresponds to the average of 2 replicates for the topsoil layer.

\subsection{Changes in the bast tissues}

\subsubsection{Evolution in bast tissue architecture}

At the initial state, the bast tissues surrounding the inner xylem core consisted of different structures, such as the epidermis (a cuticle and epidermal cells beneath), cortical parenchyma and fibre bundles (Fig. 8a,b) in the parenchyma. The fibre lumen was almost non-existent for the MAT stems, indicating that the cell wall of the bast fibres was thicker in the MAT stems than in the FLO stems, where the lumen could be clearly observed (Fig. 8a,b). Such incomplete thickening of the cell walls may lead to a certain heterogeneity for FLO stem samples, whose fiber bundles may show some fragmentation when sectioning FLO stem prior to SEM observation (Fig. 8a). While bacteria and fungi were observed on the stem surface for both hemp qualities on day 14 (Fig. $8 \mathrm{~cd}$ ), as previously observed (Fig. 3), their widespread colonization on the FLO stems reached the underlying epidermis and cortical parenchyma, leading to degradation (Fig. 8c). An alteration in the bast tissue architecture was observed on day 28 , resulting from the advanced parenchyma degradation for both the FLO and MAT stems (Fig. 8e,f), but fibre bundle decohesion occurred only for the FLO stems, leading to a decrease in the area of the fibre bundles (Fig. 8e). At day 42, fibre bundle decohesion continued for the FLO stems, leading to an individualization of the elementary fibres (Fig. 8g); in contrast, the slower retting observed for the MAT stems resulted in a degree of fibre bundle decohesion equivalent to that observed for the FLO stems on day 28 (Fig. $8 h)$.
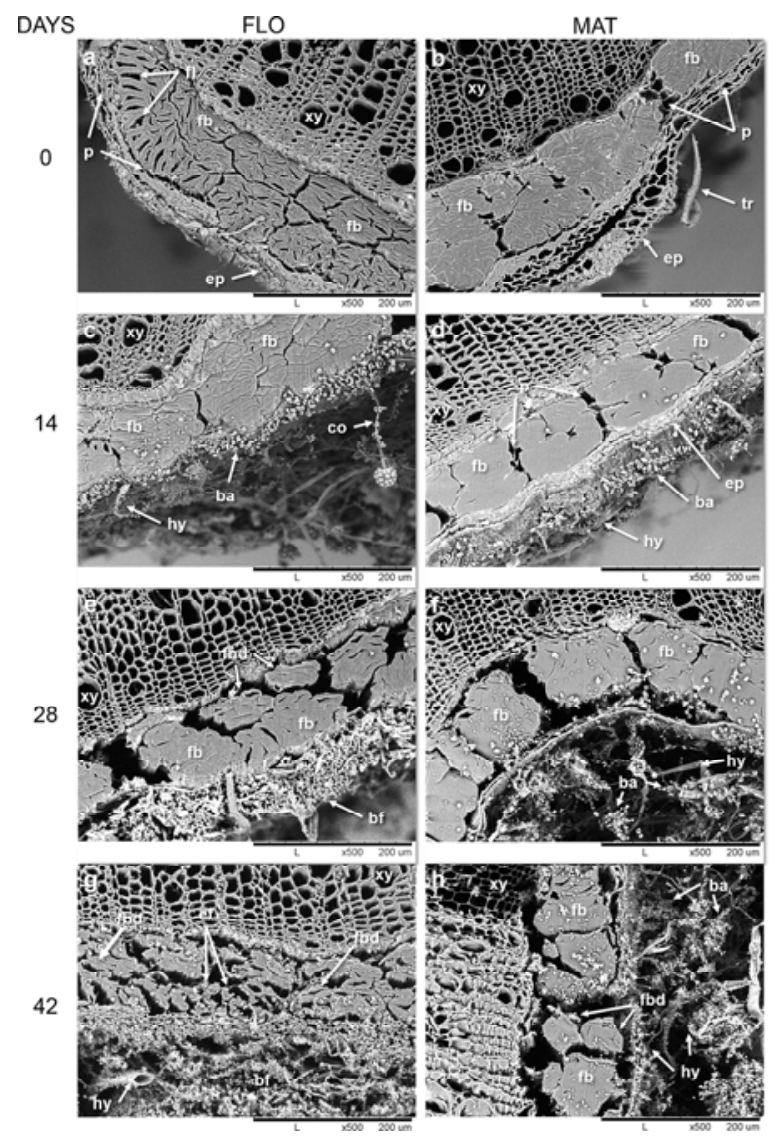

Fig. 8 SEM images of the transverse sections of FLO (a, c, e, and g) and MAT stems (b, d, f, and h) during retting. Before retting (a,b), after $14(\mathrm{c}, \mathrm{d}), 28(\mathrm{e}, \mathrm{f})$ and 42 days (g,h) of retting; (ba) bacteria, (bf) biofilm, (co) conidiophore, (ef) elementary fibre, (ep) epidermis, (fb) fibre bundle, (fbd) fibre bundle decohesion, (fl) fibre lumen, (hy) hyphae, (mc) microbial colonization, (p) parenchyma, (tr) trichome and (xy) xylem. Scale bar $=200 \mu \mathrm{m}$. 
Post-print version (25/01/2020) of the paper published in Industrial Crops and Products, volume 145, March 2020, 112122 https://www.sciencedirect.com/science/article/abs/pii/S0926669020300388 https://doi.org/10.1016/j.indcrop.2020.112122

\subsubsection{Changes in bast tissue chemical composition and} enzyme dynamics

The Van Soest fractionation results indicate that the initial FLO and MAT bast tissue compositions differed significantly only for the CEL (572 \pm 3 vs $626 \pm 6 \mathrm{~g} / \mathrm{kg}$ total initial DM and SOL fractions $(307 \pm 1$ vs $244 \pm 3 \mathrm{~g} / \mathrm{kg}$ total initial DM) (supplementary material Fig.1). The cell wall contents $(\mathrm{CEL}+\mathrm{HEM}+\mathrm{LIG})$ were significantly different, with $687 \pm 1$ and $751 \pm 7 \mathrm{~g} / \mathrm{kg}$ initial DM for the FLO and MAT stems, respectively. However, the initial LIG content of the bast tissue CWR, assayed with the acetyl bromide method, varied significantly according to the hemp quality and was higher for the MAT stem (Fig. 9a). The contents of galacturonic acid and arabinose, pectin indicators of the middle lamella and primary cell walls in parenchyma and fibre bundles, were not significantly different in the FLO and MAT stems before retting (Fig. 9 b,c). The content of these monosaccharides showed a similar decrease during the first 14 days, followed by a plateau until day 42 . Stem quality had only a significant effect on arabinose content (Fig. 9 b,c). The PGase activity, related to pectin degradation and a lower proportion of galacturonic acid, showed a significant increase during the first 7 days for both FLO and MAT (data not shown). Both glucose and LIG contents significantly increased during retting (Fig. 9 a,d). LIG is located in the middle lamellae and primary cell wall of the fibre bundles, and glucose can mostly be attributed with the CEL of the fibre secondary cell wall. These results indicate that the bast tissue degradation during retting was selective and mostly concerned the parenchyma cell wall; additionally, to a lesser extent, the middle lamellae and primary cell wall of the fibre bundles preserved the secondary cell wall of the fibres.

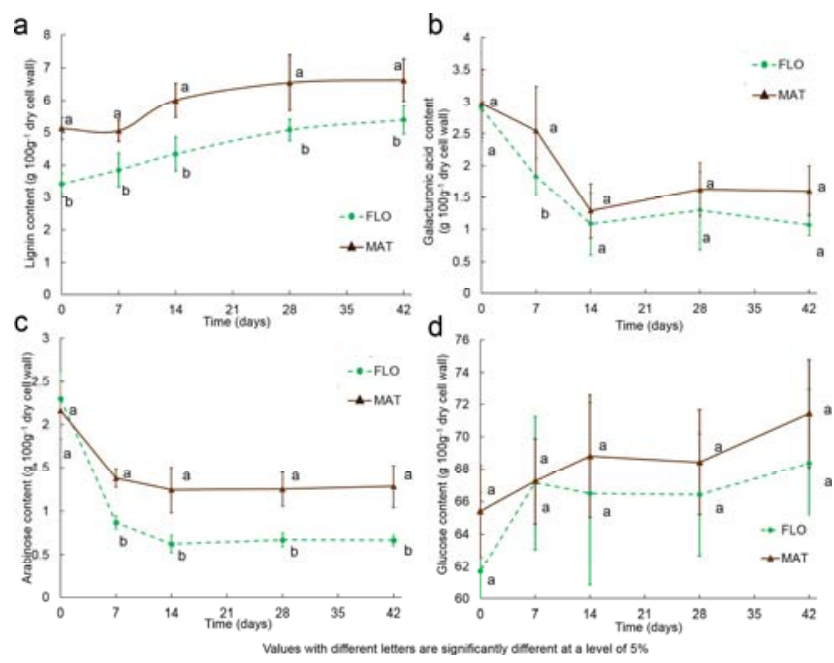

Fig. 9 Changes in the chemical composition of the cell wall residues (CWR) of the hemp bast tissues. The LIG (a), galacturonic acid (b), arabinose (c) and glucose (d) contents depend on the hemp harvest time during retting.

\section{Discussion}

The objective of this study was to determine how hemp stem quality linked to the hemp harvest time modifies dew retting microbial dynamics by quantifying the different processes, such as microbial colonization and degradation involved in retting. The hypothesis of this study was that the chemical composition of hemp stems harvested at the flowering stage is susceptible to ret faster than stems harvested at seed maturity. In a recent study, we designed an experimental procedure to perform hemp retting at the laboratory scale reproducing the hemp retting process while accurately controlling the retting drivers (Bleuze et al., 2018). Retting of fibre crops as hemp and flax has been related to the action of different microorganisms which are mainly found in soil (Ribeiro et al., 2015; Djemiel et al., 2017). In the present study, we focused on the initial features of the hemp stems and their effects on microbial colonization and retting rate.

The main effect of an earlier harvest time, such as the flowering stage, on the hemp stem quality was reflected by several elements. At the whole-stem level, the flowering stems contained higher soluble $\mathrm{C}$ fractions and lower CEL and LIG fractions than the mature stems. Previous studies also reported a decrease in the contents of soluble carbohydrates, water-soluble extractives and extractives with a later harvest time (Kreuger et al., 2011; Godin et al., 2013). Moreover, lower CEL and LIG contents were previously observed for hemp stems harvested at the flowering stage (Struik et al., 2000; Kreuger et al., 2011). The decrease in the ratio of SOL to cell wall contents during the ripening of the seed can be explained by the thickening of the secondary cell wall of the fibres during this period, followed by the lignification of the middle lamellae and primary cell wall of the fibre bundles (Struik et al., 2000; Keller et al., 2001; Crônier et al., 2005). At the bast tissue level, the main changes were a higher SOL fraction and lower CEL, LIG and cell wall contents at flowering than at the mature state. Increases in the cell wall, CEL, and LIG contents in the bast tissues during hemp maturation have been reported (Keller et al., 2001; Crônier et al., 2005), and the results are in the same range as ours. The changes in chemical composition during hemp stem maturation can influence the subsequent microbial degradation of the stems, as observed for wheat stems (Bertrand et al., 2006), with the proportion of the SOL fraction being positively correlated with the degradation rate in the early phases of litter decomposition (Berg and McClaugherty, 2008). A study on mulch decomposition under controlled environmental conditions showed that after 41 days, mulch loss was approximately $17 \%$ initial DM for the mulch with $25 \%$ SOL and $26 \%$ HEM, while mulch loss was only $11 \%$ initial DM for the mulch with $22 \%$ SOL and $29 \%$ HEM (Iqbal et al., 2015). These results suggest that the effects of the initial quality on microbial growth and activity are significant, even with relatively small differences in 
Post-print version (25/01/2020) of the paper published in Industrial Crops and Products, volume 145, March 2020, 112122 https://www.sciencedirect.com/science/article/abs/pii/S0926669020300388 https://doi.org/10.1016/j.indcrop.2020.112122

composition. This may induce variation in the composition of communities colonizing the stems; however the same species were present according to soil type, harvest dates and retting duration albeit in different proportion (Ribeiro et al., 2015). In the present study, the range of stem DM losses after 42 days was 18 and $14 \%$ initial DM for FLO and MAT stems, respectively, in the range previously reported (Iqbal et al., 2015). This finding indicates that the initial SOL pool plays an important role in the early decomposition process and that the retting process can be regarded as an early phase of litter decomposition.

The first "visible" modification of the hemp stems during retting was their surface colonization by soil microorganisms. Colonization was faster for the stems harvested at flowering (7-day time lag), consistent with the higher contents of $\mathrm{C}$ and other soluble compounds, than for mature stems. Indeed, after the first rain, part of the SOL fraction leached down into the topsoil layer $(+19 \%$ of the soluble $\mathrm{C}$ in the topsoil layer), boosting the growth of microorganisms and the observed colonization of the stem. The early leaching from plant residues to the topsoil layer has also been observed earlier (Coppens et al., 2006; Iqbal et al., 2015), providing readily available compounds regulating microbial growth (Berg and McClaugherty, 2008; Lashermes et al., 2016). In the present study, the progressive microbial colonization was reflected by changes in both the stem surface colour and outermost layer composition. These two measurements revealed a difference in kinetics between the two stem qualities, thus providing potential indicators of the retting colonization dynamics. The chemical composition of the outermost layer of the FLO stems showed an evolution in infrared spectra between day 0 and day 7. Although less pronounced, similar changes occurred for the MAT stems at the earlier stages of retting. These changes could be related to the masking of the cuticle due to microbial colonization (Bleuze et al., 2018). Stem surface colour change was previously found to be linked to microbial colonization during dew retting in both qualitative (Ribeiro et al., 2015; Mazian et al., 2018) and quantitative terms (Bleuze et al., 2018). This phenomenon is confirmed by this work with a significant correlation between the colorimetry values and the absorbance of cuticle vibration bands. However, colorimetry could be a relevant indicator, with a broader meaning than microbial colonization, and could reflect other chemical changes, as previously reported. For instance, the stem extractive degradation was previously monitored by colorimetry after the heat treatment of wood (Vinha et al., 2015). The color changes was also used to assess the photodegradation of bio-composites inducing surface yellowing and bleaching caused by the exposure to a combination of UV and humidity (Soccalingame et al., 2016). The accumulation of aromatic compounds during wheat straw delignification by fungi was also examined by colorimetry (Dorado et al., 1999).
As soon as microbial colonization initiates, fungi can modify the local environment by transferring water and nutriments and facilitating the transport of bacteria participating in biofilm formation (Frey-Klett et al., 2011). Different hypotheses could explain the much faster development of biofilm at the surface of stems at the flowering stage. First, hemp harvested at flowering could have a cuticle with a more labile chemical composition and a lower thickness than mature hemp because cuticle biosynthesis continues until the maturity stage (Riederer and Schönherr, 1988; Yeats and Rose, 2013). Second, the accumulation of other molecules, such as tannins and essential oils, might vary over the plant growth stage, as observed in leaves or fruits, and could inhibit the microbial colonization of mature stems (Canhoto and Graça, 1999). The colonization of the beneath bast tissues of both FLO and MAT stems took advantage of the opening in the cuticle, notably the remnant of trichomes, as previously observed on olive skin and leaf litter with preferential colonization in the stomatal opening or fissures (Canhoto and Graça, 1999; Nychas et al., 2002). The 7-day time difference in the microbial colonization of the stem surface between the two hemp qualities has been extended during the subsequent degradation of the bast tissues, based on the observation of the fibre bundle decohesion state. The increased retting delay between the two stem qualities (approximately 14 days, although the time between the last two measurements does not allow this estimate to be refined) can be explained by the chemical composition of the bast tissues. The FLO stems had higher SOL fractions and lower LIG and cell wall contents, providing more labile and easily assimilated compounds as well as accelerating bast tissue degradation, than MAT stems, which have more recalcitrant bast tissues and slower degradation. In addition, the secondary wall thickening and subsequent lignification of the middle lamellae of the fibre bundles during ripening (Struik et al., 2000; Crônier et al., 2005) can also impact the physical properties of the fibre bundles, possibly slowing down degradation. Lastly, the biofilm observed on day 42 on the FLO stems can induce optimal micro-physicochemical conditions, such as $\mathrm{pH}$ modification, with the synthesis of the exopolymeric matrix, as previously reported (Frey-Klett et al., 2011), boosting the bast tissue degradation.

Even if the dynamics of retting were significantly modified, the processes involved remained identical for the two stem qualities. This finding indicates that the kinetics obtained in this study at $15{ }^{\circ} \mathrm{C}$ could be reasonably well extrapolated to other retting temperature conditions, particularly field conditions, by using a temperature response function (Brisson et al., 2009). Using the average daily temperature data over 25 years (1990-2015) of the area where the hemp was cultivated for this study, the retting duration of 28 days at $15{ }^{\circ} \mathrm{C}$ of flowering hemp stems would equal 13 to 22 days for the mean daily temperatures of 22 and $17{ }^{\circ} \mathrm{C}$, respectively (range of temperature in August, period of dew 
Post-print version (25/01/2020) of the paper published in Industrial Crops and Products, volume 145, March 2020, 112122 https://www.sciencedirect.com/science/article/abs/pii/S0926669020300388 https://doi.org/10.1016/j.indcrop.2020.112122

retting after flowering harvest). For mature hemp stems, the retting duration of 42 days at $15^{\circ} \mathrm{C}$ would equal 30 to 59 days of retting in the field over a period (September) with mean daily temperatures of 18 and $12{ }^{\circ} \mathrm{C}$, respectively. We therefore show that in the field, differences in stem composition due to the crop harvest strategy may have significant consequences on dew retting duration and therefore on plot occupancy by on-going retting and subsequent plot availability. This fine characterization of microbial colonization and substrate degradation during retting process together with the quantification of kinetics allows us to consider the possibility of modelling such a microbial process to predict retting as a function of initial stem characteristics and climatic conditions. The "BioRetting" model, currently under development, will be able then to take into account the initial tissue and polymers composition of FLO and MAT stems and simulate the effects of rain regime, air moisture and temperature on the microbial degradation during retting process, and to test different climate scenario for a single type of hemp stems.

\section{Conclusion}

Hemp harvest time had a significant effect on the initial chemical composition of stems and on the microbial dynamics of retting. These differences were revealed by both microbial colonization kinetic and biofilm formation and were reflected by changes in the color of the stem surface but also by the selective degradation of the bast tissue parenchyma and middle lamella fibre bundles. Notably, all other conditions being equal under the controlled climate approach chosen for this study, the differences in the initial stem composition significantly affected the retting time but not the nature and succession of the processes. This retting duration, based on the observed fibre bundle decohesion, was reduced by approximately 2 weeks at $15{ }^{\circ} \mathrm{C}$ for the hemp harvested at the flowering stage compared to that for the mature stems. These results indicate that accurately quantifying and modelling the individual effects of drivers such as hemp quality on microbial dynamics and subsequently on retting duration is possible. Other microbial drivers, such as air temperature, rain regime and soil type, could be studied with such reproducible and controlled conditions to better predict the dew retting process in the field and improve the farmer's retting management. Moreover it point to the need of further studies on the microbial communities involved and biofilm formation that are still poorly known for fiber-plant dew retting.

Electronic supplementary material The online version of this article contains supplementary materials, which is available to authorized users.
Funding Information This work was funded by the Environment and Agronomy Division of INRAE and Reims Métropole within the framework of the MATRICE project.

\section{CRediT authorship contribution statement}

Laurent Bleuze: Methodology, Investigation, Formal analysis, Writing -original draft; Brigitte Chabbert: Conceptualization, Supervision, Writing - Review and editing, Funding acquisition; Gwenaëlle Lashermes: Conceptualization, Supervision, Writing - Review and editing; Sylvie Recous: Conceptualization, Supervision, Writing - Review and editing, Project administrator.

Declaration of Competing Interest The authors declare that they have no conflict of interest.

Acknowledgments The authors thank La Chanvrière (Bar sur Aube, France) for growing hemp, the technical staff of FARE laboratory (G. Alavoine, F. Gaudard, A. Habrant, S. Millon and F. Phillipe) for their technical assistance during this study, GEGENAA Laboratory (Université de Reims Champagne Ardenne) for SEM and colorimetry facilities. The authors also thank Dr Ludovic Besaury for his review on a previous version of the manuscript and whose suggestions greatly improved this work.

\section{References}

Akin, D.E., Rigsby, L.L., Morrison III, W.H., 2004. Oil Red as a histochemical stain for natural fibers and plant cuticle. Ind. Crops Prod. 19, 119-124. https://doi.org/10.1016/j.indcrop.2003.08.002

Amaducci, S., Gusovius, H.-J., 2010. Chapter 6. Hemp Cultivation, Extraction and Processing, in: Müssig, J. (Ed.), Industrial Applications of Natural Fibres: Structure, Properties and Technical Applications. John Wiley \& Sons, Ltd, Chichester, UK, pp. 109-134. https://doi.org/10.1002/9780470660324.ch5

Amaducci, S., Scordia, D., Liu, F.H., Zhang, Q., Guo, H., Testa, G., Cosentino, S.L., 2015. Key cultivation techniques for hemp in Europe and China. Ind. Crops Prod., 68, 2-16. https://doi.org/10.1016/j.indcrop.2014.06.041

Barcelona, M.J., 1984. TOC Determinations in Ground Water. Groundwater 22, 18-24. https://doi.org/10.1111/j.17456584.1984.tb01471.x

Belmokhtar, N., Habrant, A., Ferreira, N.L., Chabbert, B., 2013. Changes in phenolics distribution after chemical pretreatment and enzymatic conversion of Miscanthus $\mathrm{x}$ giganteus internode. BioEnergy Res. 6, 506-518. https://doi.org/10.1007/s12155-0129275-2

Bennett, S.J., Snell, R., Wright, D., 2006. Effect of variety, seed rate and time of cutting on fibre yield of dew-retted hemp. Ind. Crops Prod. 24, 79-86. https://doi.org/10.1016/j.indcrop.2006.03.007

Berg, B., McClaugherty, C., 2008. Chapter 5 Changes in substrate composition during decomposition, in: Plant Litter: 
Post-print version (25/01/2020) of the paper published in Industrial Crops and Products, volume 145, March 2020, 112122 https://www.sciencedirect.com/science/article/abs/pii/S0926669020300388 https://doi.org/10.1016/j.indcrop.2020.112122

Decomposition, Humus Formation, Carbon Sequestration. Springer, Berlin, Heidelberg, pp. 85-114.

Bertrand, I., Chabbert, B., Kurek, B., Recous, S., 2006. Can the biochemical features and histology of wheat residues explain their decomposition in soil? Plant Soil 281, 291-307. https://doi.org/10.1007/s11104-005-4628-7

Bleuze, L., Lashermes, G., Alavoine, G., Recous, S., Chabbert, B., 2018. Tracking the dynamics of hemp dew retting under controlled environmental conditions. Ind. Crops Prod. 123, 55-63. https://doi.org/10.1016/j.indcrop.2018.06.054

Bouloc, P., 2006. Le chanvre industriel: production et utilisations. France Agricole Editions.

Brisson, N., Launay, M., Mary, B., Beaudoin, N. (Eds.), 2009. Conceptual Basis, Formalisations and Parameterization of the Stics Crop Model, Quae. ed, Update Sciences \& technologies. Versailles.

Canhoto, C., Graça, M. a. S., 1999. Leaf Barriers to Fungal Colonization and Shredders (Tipula lateralis) Consumption of Decomposing Eucalyptus globulus. Microb. Ecol. 37, 163-172. https://doi.org/10.1007/s002489900140

Coppens, F., Garnier, P., De Gryze, S., Merckx, R., Recous, S., 2006. Soil moisture, carbon and nitrogen dynamics following incorporation and surface application of labelled crop residues in soil columns. Eur. J. Soil Sci. 57, 894-905. https://doi.org/10.1111/j.1365-2389.2006.00783.x

Crônier, D., Monties, B., Chabbert, B., 2005. Structure and chemical composition of bast fibers isolated from developing hemp stem. J. Agric. Food Chem. 53, 8279-8289. https://doi.org/10.1021/jf051253k

Djemiel, C., Grec, S., Hawkins, S., 2017. Characterization of Bacterial and Fungal Community Dynamics by High-Throughput Sequencing (HTS) Metabarcoding during Flax Dew-Retting. Front. Microbiol. 8, 2052. https://doi.org/10.3389/fmicb.2017.02052

Dorado, J., Almendros, G., Camarero, S., Martínez, A.T., Vares, T., Hatakka, A., 1999. Transformation of wheat straw in the course of solid-state fermentation by four ligninolytic basidiomycetes. Enzyme Microb. Technol. 25, 605-612. https://doi.org/10.1016/S0141-0229(99)00088-5

Fernando, D., Thygesen, A., Meyer, A.S., Daniel, G., 2019. Elucidating Field Retting Mechanisms of Hemp Fibres for Biocomposites: Effects of Microbial Actions and Interactions on the Cellular Micro-morphology and Ultrastructure of Hemp Stems and Bast Fibres. BioResources 14, 4047-4084.

Frey-Klett, P., Burlinson, P., Deveau, A., Barret, M., Tarkka, M., Sarniguet, A., 2011. Bacterial-Fungal Interactions: Hyphens between Agricultural, Clinical, Environmental, and Food Microbiologists. Microbiol. Mol. Biol. Rev. MMBR 75, 583-609. https://doi.org/10.1128/MMBR.00020-11

Godin, B., Lamaudière, S., Agneessens, R., Schmit, T., Goffart, J.-P., Stilmant, D., Gerin, P.A., Delcarte, J., 2013. Chemical characteristics and biofuels potentials of various plant biomasses: influence of the harvesting date. J. Sci. Food Agric. 93, 3216-3224. https://doi.org/10.1002/jsfa.6159

Heredia-Guerrero, J.A., Benítez, J.J., Domínguez, E., Bayer, I.S., Cingolani, R., Athanassiou, A., Heredia, A., 2016. Infrared spectroscopy as a tool to study plant cuticles. Spectrosc. Eur. 28, 10 13.

Iqbal, A., Aslam, S., Alavoine, G., Benoit, P., Garnier, P., Recous, S., 2015. Rain regime and soil type affect the $\mathrm{C}$ and $\mathrm{N}$ dynamics in soil columns that are covered with mixed-species mulches. Plant Soil 393, 319-334. https://doi.org/10.1007/s11104015-2501-x

Johnson, D.B., Moore, W.E., Zank, L.C., 1961. The spectrophotometric determination of lignin in small wood samples. Tappi 44, 793-798.

Kamphake, L.J., Hannah, S.A., Cohen, J.M., 1967. Automated analysis for nitrate by hydrazine reduction. Water Res. 1, 205-216. https://doi.org/10.1016/0043-1354(67)90011-5

Keller, A., Leupin, M., Mediavilla, V., Wintermantel, E., 2001. Influence of the growth stage of industrial hemp on chemical and physical properties of the fibres. Ind. Crops Prod. 13, 35-48. https://doi.org/10.1016/S0926-6690(00)00051-0

Kreuger, E., Prade, T., Escobar, F., Svensson, S.-E., Englund, J.-E., Björnsson, L., 2011. Anaerobic digestion of industrial hempEffect of harvest time on methane energy yield per hectare. Biomass Bioenergy 35, 893-900. https://doi.org/10.1016/j.biombioe.2010.11.005

Krom, M.D., 1980. Spectrophotometric determination of ammonia: a study of a modified Berthelot reaction using salicylate and dichloroisocyanurate. Analyst 105, 305-316. https://doi.org/10.1039/AN9800500305

Lashermes, G., Gainvors-Claisse, A., Recous, S., Bertrand, I., 2016. Enzymatic strategies and carbon use efficiency of a litterdecomposing fungus grown on maize leaves, stems, and roots. Front. Microbiol. 7, 1315. https://doi.org/10.3389/fmicb.2016.01315

Liu, M., Fernando, D., Daniel, G., Madsen, B., Meyer, A.S., Ale, M.T., Thygesen, A., 2015. Effect of harvest time and field retting duration on the chemical composition, morphology and mechanical properties of hemp fibers. Ind. Crops Prod. 69, 29-39. https://doi.org/10.1016/j.indcrop.2015.02.010

Machinet, G.E., Bertrand, I., Barrière, Y., Chabbert, B., Recous, S., 2011. Impact of plant cell wall network on biodegradation in soil: Role of lignin composition and phenolic acids in roots from 16 maize genotypes. Soil Biol. Biochem. 43, 1544 1552. https://doi.org/10.1016/j.soilbio.2011.04.002

Mazian, B., Bergeret, A., Benezet, J.-C., Malhautier, L., 2018. Influence of field retting duration on the biochemical, microstructural, thermal and mechanical properties of hemp fibres harvested at the beginning of flowering. Ind. Crops Prod. 116, 170 181. https://doi.org/10.1016/j.indcrop.2018.02.062

McGuire, R.G., 1992. Reporting of objective color measurements. HortScience 27, 1254-1255.

Mediavilla, V., Jonquera, M., Schmid-Slembrouck, I., Soldati, A., 1998. Decimal code for growth stages of hemp (Cannabis sativa L.). J. Int. Hemp Assoc. 5, 68-74.

Mediavilla, V., Leupin, M., Keller, A., 2001. Influence of the growth stage of industrial hemp on the yield formation in relation to certain fibre quality traits. Ind. Crops Prod. 13, 49-56. https://doi.org/10.1016/S0926-6690(00)00052-2 
Post-print version (25/01/2020) of the paper published in Industrial Crops and Products, volume 145, March 2020, 112122 https://www.sciencedirect.com/science/article/abs/pii/S0926669020300388 https://doi.org/10.1016/j.indcrop.2020.112122

Miller, G.L., 1959. Use of dinitrosalicylic acid reagent for determination of reducing sugar. Anal. Chem. 31, 426-428. https://doi.org/10.1021/ac60147a030

Müssig, J., Martens, R. 2003. Quality Aspects in Hemp Fibre Production-Influence of Cultivation, Harvesting and retting. J. Ind. Hemp, 8:1, 11-32, https://doi.org/10.1300/J237v08n01_03

Nicolardot, B., Bouziri, L., Bastian, F., Ranjard, L., 2007. A microcosm experiment to evaluate the influence of location and quality of plant residues on residue decomposition and genetic structure of soil microbial communities. Soil Biol. Biochem. 39, 1631-1644. https://doi.org/10.1016/j.soilbio.2007.01.012

Nychas, G.J.E., Panagou, E.Z., Parker, M.L., Waldron, K.W., Tassou, C.C., 2002. Microbial colonization of naturally black olives during fermentation and associated biochemical activities in the cover brine. Lett. Appl. Microbiol. 34, 173-177. https://doi.org/10.1046/j.1472-765x.2002.01077.x

Réquilé, S., Le Duigou, A., Bourmaud, A., Baley, C., 2018. Peeling experiments for hemp retting characterization targeting biocomposites. Ind. Crops Prod. 123, 573-580. https://doi.org/10.1016/j.indcrop.2018.07.01

Ribeiro, A., Pochart, P., Day, A., Mennuni, S., Bono, P., Baret, J.-L., Spadoni, J.-L., Mangin, I., 2015. Microbial diversity observed during hemp retting. Appl. Microbiol. Biotechnol. 99, 4471-4484. https://doi.org/10.1007/s00253-014-6356-5

Riederer, M., Schönherr, J., 1988. Development of plant cuticles: fine structure and cutin composition of Clivia miniata Reg. leaves. Planta 174, 127-138. https://doi.org/10.1007/BF00394885

Sisti, L., Totaro, G., Vannini, M., Celli, A., 2018. Retting process as a pretreatment of natural fibers for the development of polymer composites, in: Lignocellulosic Composite Materials, Springer Series on Polymer and Composite Materials. Springer, Cham, pp. 97-135. https://doi.org/10.1007/978-3-319-68696-7_2

Soccalingame, L., Perrin, D., Bénézet, J.-C., Bergeret, A., 2016. Reprocessing of UV-weathered wood flour reinforced

\section{Electronic supplementary material}

\section{SM Fig. 1: Initial Van Soest fraction contents of stem bast tissues}

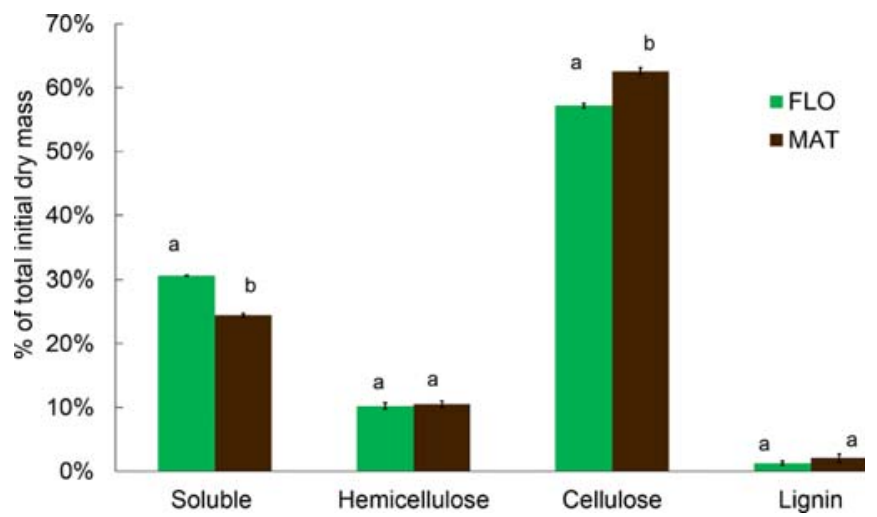

polypropylene composites: Study of a natural outdoor exposure. $\begin{array}{llll}\text { Polym. } & \text { Degrad. } & \text { 389-398. }\end{array}$ https://doi.org/10.1016/j.polymdegradstab.2016.09.011

Struik, P.C., Amaducci, S., Bullard, M.J., Stutterheim, N.C., Venturi, G., Cromack, H.T.H., 2000. Agronomy of fibre hemp (Cannabis sativa L.) in Europe. Ind. Crops Prod. 11, 107-118. https://doi.org/10.1016/S0926-6690(99)00048-5

Tahir, P., Ahmed, A., SaifulAzry, S., Ahmed, Z., 2011. Retting process of some bast plant fibres and its effect on fibre quality: a review. Bioresources 6, 5260-5281. https://doi.org/10.15376/biores.6.4.5260-5281

Terres Inovia, 2017. Guide cultural du chanvre: Semis du chanvre. Retrieved December 2, 2019 from https://www.terresinovia.fr/documents/20126/453413/Guide_chanv re_2017_Terres-Inovia.pdf/a112d08b-6632-f114-6c8722344394 c6af? $\mathrm{t}=1553962904793$.

Van Soest, P.J., 1963. Use of detergents in the analysis of fibrous feeds. 1. Preparation of fiber residues of low nitrogen content. J. Assoc. Off. Anal. Chem. 46, 825-835.

Van Soest, P.J., Robertson, J.B., Lewis, B. A., 1991. Methods for dietary fiber, neutral detergent fiber and nonstarch polysaccharides in relation to animal nutrition. J. Dairy Sci., 74, 3583-3597. DOI: 10.3168/jds.S0022-0302(91)78551-2

Vinha, A.J., Carvalho, A.G., Teixeira de Souza, M., Marangon Jardim, C., de Cassia Oliveira Carneiro, A., Luiz Colodette, J., 2015. Effect of extractives on wood color of heat treated Pinus radiata and Eucalyptus pellita. Maderas Cienc. Tecnol. 17, 857-864. https://doi.org/10.4067/S0718-221X2015005000074

Yeats, T.H., Rose, J.K.C., 2013. The formation and function of plant cuticles. Plant Physiol. 163, 5-20. https://doi.org/10.1104/pp.113.222737 